\title{
Writing Resistance, Writing the Self: Literary Reconstruction in United States Prison Witness
}

Escrever a resistência, escrever o eu: reconstrução literária em testemunhos de prisão nos Estados Unidos

Écrire la résistance, écrire le moi: reconstruction littéraire en témoignages de prison aux États-Unis

Doran Larson

\section{OpenEdition}

\section{Journals}

Electronic version

URL: http://journals.openedition.org/rccs/9840

DOI: $10.4000 /$ rccs. 9840

ISSN: 2182-7435

\section{Publisher}

Centro de Estudos Sociais da Universidade de Coimbra

Printed version

Date of publication: 1 December 2019

Number of pages: 161-182

ISSN: 0254-1106

\section{Electronic reference}

Doran Larson, « Writing Resistance, Writing the Self: Literary Reconstruction in United States Prison Witness », Revista Crítica de Ciências Sociais [Online], 120 | 2019, Online since 12 December 2019, connection on 14 December 2019. URL : http://journals.openedition.org/rccs/9840 ; DOI : 10.4000/ rccs. 9840 


\section{DORAN LARSON}

\section{Writing Resistance, Writing the Self: Literary Reconstruction in United States Prison Witness}

Based in a digital archive of first-person witness by people currently incarcerated in the United States (U.S.), this paper discusses witness texts that document and grieve the experience of alienation of self-identity, fight that alienation, and that together map both the degradation of human dignity at the center of current U.S. penality and how it can be resisted in restoring sociality with other incarcerated people. Writing from inside often represents a moment not only of resistance to the prison regime, but of reconstruction of the self that is the premise for all further resistance. After placing prison witness today against the background of such witness from an earlier penal era, the paper looks at patterns across the essays currently posted in the American Prison Writing Archive (APWA). The paper suggests that the very availability of the APWA could re-ground future U.S. prison scholarship.

Keywords: archive; human dignity; prison; socialization; testimony; United States of America.

\section{Premises}

American legal scholar Robert Cover observes regarding legal decisions, "[T] he function of ideology is much more significant in justifying an order to those who principally benefit from it and who must defend it than it is in hiding the nature of the order from those who are its victims" (1992: 212). Critical politic action and the testimony of political prisoners measure the distance between law's beneficiaries and victims, between democratic claims and police tactics, or name the concentricity of claims and tactics inside unabashed police states. Inside the earth's largest carceral state, however, those who enter prison with fully formed, explanatory political viewpoints are the exception among a population plagued by poverty and illiteracy (Western, 2006; Wacquant, 2009). More commonly, political awareness is the product of imprisonment itself (Shakur, 1987: 52; Abbott, 1991: 95; Uggen and Manza, 2004: 169). 
Incarcerated people who write about their experience engage in acts of resistance to a prison regime whose abuses thrive in darkness, inside spaces of de facto quarantine from law's rule (Franklin, 1989; Dayan, 2011). Indeed, it is the writing of those who are not sustained by fully-realized political positions that most intimately records the depths of psychological and emotional degradation at the center of the U.S. carceral state. ${ }^{1}$ In turn, psychological and emotional resistance to this center, once translated into words, is the starting point, the ground zero of carceral resistance (Larson, 2017: 27-64). As Judith Butler writes of poems by Guantánamo detainees, this is writing "as evidence and appeal, in which each word is finally meant for another" (2009: 59); and that appeal is the basis for a restored, resistant sociality. Witnesses inside the U.S. prison today present autobiographies shaped by carceral-state poverty (and all of its damaging social effects), hyper-policing, racialized courts, and prisons that assault and degrade human dignity (Simon, 2014) - a carceral regime that, as Colin Dayan notes, metes out "state-sanctioned degradation [...] propelled by a focus on personal identity, the terms by which personality is recognized, threatened, or removed" (2011: xii). Yet such witnesses also document resilient self-command, resistant reconstruction of the self that the prison alienates. Rather than countering carceral-state ideology from an alternative ideological position (though writers certainly do develop this capacity; e.g. Holbrook, 2019), the writers of concern here are those who resist the carceral state from inside the minds and hearts of its victims; they insist upon their full humanity even as they document its state-sponsored degradation.

Much of the evidence for this paper will be drawn from The American Prison Writing Archive (APWA), the largest and first fully-searchable digital archive of non-fiction essays by incarcerated people writing about their experience of confinement. Unlike traditional venues for literary expression

\footnotetext{
${ }^{1}$ This echoes Jean Améry's observation from the death camps: those with political or religious convictions fare better than those without, in the sense that they bring worldviews that give some teleological sense to the camps (Améry, 1980: 13) - though to ends distinct from the incarcerated: camp inhabitants can simplify by unifying their experience; the political views of the incarcerated often complicate their understanding. Without such frames of reference, as we will see, the prison writer confronts every aspect of incarceration as part of a dynamic, unfolding assault. In a practical sense, Agamben's definition of the extra-judicial camp appears to describe U.S. prisons today: "[...] a space in which [...] the normal rule of law is suspended and in which the fact that atrocities may or may not be committed does not depend on the law but rather on the civility and ethical sense of the police that act temporarily as sovereign" (Agamben, 2003: 241-245). The law is not suspended in U.S. prisons; it is, however, extremely difficult to access, even in face of egregious officer violence (ACLU, 2002; Robbins, 2015). In this essay I assume a conventional distinction between political prisoners and other incarcerated people (cf. Rodriguez, 2006: 5).
} 
- both in print and online - the work in the APWA is not selected by the gatekeepers among agents, book or magazine editors, book-marketing consultants, writing contest judges, etc. Incarcerated people need only a stamp, an envelope, and paper to request the APWA permission-questionnaire (from which all archive metadata are gathered; see APWA, 2019), and a second stamp (or stamps) and envelope with which to submit their essays. ${ }^{2}$ Writing can be as slight as a few lines scrawled on a scrap of paper, allowing an unprecedented level of documentation of prison experience. ${ }^{3}$ The very existence of this resource carries implications for prison scholarship. To set the context for this claim, and to underline the distinctiveness of testimony from mass incarceration, I begin with a brief review of the work of three imprisoned Americans who became writers inside a very different prison system.

\section{Precedents}

From the end of the Second World War to around 1972, U.S. prisons saw a rehabilitative turn in which the word "punishment" itself became taboo among prison officials (Simon, 2000: 287; Garland, 2002: 9). In today's era of "penal harm", the prison is space for unceasing punishment (Travis and Western, 2017: 307); this era, Craig Haney writes, "has ripped us from the ethical moorings that once held this punitive system in check, [and] [...] ensured that $[\ldots]$ crime control policy was guided [...] by some minimal humanitarian considerations" (Haney, 1998: 32). Carceral writing in the years just before 1972 thus stands in contrast to the witness from today's mass prisons, in which recovery of human, or what Butler (2009) calls "grievable" status, has become a primary field of resistance. ${ }^{4}$

Though the son of a follower of Marcus Garvey, Malcolm Little turned away from hustling drugs and trafficking women only in prison, in following Nation of Islam founder Elijah Muhammed's vision of the prison as a system of control of Black men (Malcolm X, 1965: 169-190). Rigorous self-education and a religious awakening brought about his virtual reincarnation as Malcolm X: "I still marvel at how swiftly my previous life's thinking

\footnotetext{
${ }^{2}$ Assuming, of course, that prison regimes allow this work out. Further obstacles are that writing materials generally come from prison commissaries that exploit people earning wages (if any) counted in pennies and that the APWA call for essays appears in Prison Legal News, a journal covering legislation and courts cases relevant to incarcerated people in the U.S. and distributed in most but not all prisons.

3 This is one reason why I refer to this writing not as that of writers in any conventional sense, but of witnesses.

${ }^{4}$ On the legal implications of applying standards of human dignity to prison conditions, see Simon (2014).
} 
pattern slid away from me, like snow off a roof. It is as though someone else I knew of had lived by hustling and crime. I would be startled to catch myself thinking in a remote way of my earlier self as another person" (Malcom X, 1965: 170) - other than the person who had entered Massachusetts' Norfolk prison, at the time one of the most progressive facilities in the country. Malcolm X's book and his fearless public persona after release would be an inspiration to the political self-education of other imprisoned Black people. As poet Etheridge Knight wrote after Malcolm X's assassination, "You rocked too many boats, man./Pulled too many coasts, man./Saw through the jive. You reached the wild guys/Like me." (Knight, 1986: 48).

Another of these "wild guys" was convicted rapist Eldridge Cleaver. In Soul on Ice, Cleaver lodges bitterly bemused criticism of White power, of White envy of Black culture, and excoriates how Black men must sacrifice masculinity in exchange for peace. He also admits that once he confronted the crime of rape, he lost all self-respect: "My pride as a man dissolved and my whole fragile moral structure seemed to collapse, completely shattered. That is why I started to write. To save myself. I was very familiar with the Eldridge who came to prison, but that Eldridge no longer exists" (Cleaver, 1999: 34-35). In passing, Cleaver also notes that he lives in a block where men with clean behavior records enjoy extra privileges; he is a member of a Gavel Club, Toastmasters, and a panel of men who oversee radio access. Cleaver also grows aware, like Malcolm X, "that what had happened to me had also happened to countless other blacks and it would happen to many, many more" (ibidem: 34 ).

The images of Malcolm X and Cleaver breaking down their pasts, rejecting them, and rebuilding would have pleased the early theorists of the penitentiary (e.g. Rush, 1787). Notions of spiritual death and rebirth were the base upon which the American prison was founded (Smith, 2009). Yet this relatively benign prison era also "inadvertently contributed to mounting criticism of itself by promoting a prison intelligentsia" (Irwin, 1980: 63-64). One man among this intelligentsia would serve as both a harbinger and a putative cause of the change to come.

In 1961, George Jackson began serving a one-year-to-life sentence for $\$ 70$ gas station robbery. In 1970, Jackson published Soledad Brother, a collection of letters to family, friends, and comrades. In his letters Jackson struggles to distance himself from a mother and father who raised him to keep his head down and out of trouble..$^{5}$ In prison, Jackson reads Mao, Marx,

\footnotetext{
${ }^{5}$ Such parenting techniques drew national attention after the killing of Trayvon Martin, and Barack Obama's claim that Martin might have been his son (Obama, 2013).
} 
and Engels; he documents efforts to make himself into an efficient tool of a coming revolution, learning to live with less sleep, less food, and without emotional attachments. Soledad Brother is by turns an emotional, psychological, and political study. An active organizer of Black men inside, and implicated with two others in the murder of a prison guard, Jackson's reports none of the programming or amenities that Malcolm X and Cleaver enjoy; presaging the prison to come, his letters seem to come from a foxhole, under constant threat of racists attacks by White inmates and officers, offering an early vision of the regime described by prison witnesses today. Jackson chooses to change, as did Malcolm X and Cleaver before him. But Jackson is also pointedly aware that this change is a tactic of survival inside a prison intent on his destruction:

This [concentration] camp brings out the very best in brothers or destroys them entirely. But none are unaffected. None who leave here are normal. If I leave here alive, I'll leave nothing behind. They'll never count me among the broken men, but I can't say that I am normal either. I've been hungry too long. I've gotten angry too often. I've been lied to and insulted too many times. They've pushed me over the line from which there can be no retreat. I know that they will not be satisfied until they've pushed me out of this existence altogether. I've been the victim of so many racist attacks that I could never relax again. My reflexes will never be normal again. I'm like a dog that has gone through the K-9 process. (Jackson, 1994 [1970]: 27-28; italics in the original)

Jackson both laments and celebrates his transformation: "I feel no pain of mind or body, and the harder it gets the better I like it" (ibidem: 38). As he notes prophetically, "Men who read Lenin, Fanon, and Che don't riot, 'they mass', 'they rage', they dig graves" (ibidem: 27). Jackson's implication in an officer's murder, his book, and his killing inside San Quentin prison amid a purported escape attempt, turned him into a national icon: a martyr for the left, a wakeup call for the right. While alive, Jackson spent periods welded inside his cell. In his bloody death, he struck such deep fear into prison officials that the rise of today's supermax prisons has been traced to that day (Reiter, 2016: 3). His letters foreshadow the psychological assault and resistance that witnesses to the mass prison are documenting at this moment. Three weeks after Jackson's killing, men inside Attica raised a rebellion catalyzed in part by solidarity around his death, solidarity that would serve as one of the triggers of a newly degrading prison regime (Reiter, 2016; Thompson, 2016: 36).

The Autobiography of Malcolm X, Soul on Ice, and Soledad Brother recast in racial terms a trope of U.S. prison writing: U.S. prisons are less about 
crime control than about controlling the poor (e.g. Lyon, 1799; Snelling, 1837; O'Hare, 1920). In the 1960s, this was the message taken up by the left, which critiqued rehabilitation programs for teaching White "bourgeoise" values (Garland, 2002: 164-165). For the right, the emergence of Black prison activists, and a spate of bloody prison uprisings proved that rehabilitation was wasted on people who did not recognize the legitimacy of court practices, or (White) law itself (Simon, 2014: 17-46). Angela Davis offered an exemplary call when she wrote from Marin County Jail: "[...] we can't expect justice from a repressive judicial system and I'm sure that an exclusively legalistic approach to my defense would be fatal. So what we have to do is to talk about placing the courts on trial" (Davis, 1971: 177). Davis' view that American criminal justice enforces an "apartheid state" (Garland, 2002: 204), has been confirmed repeatedly since (Stuntz, 2001; Mauer, 2006; Western, 2006; Wacquant, 2009; Alexander, 2010; Butler, 2017). Writers like Davis confirmed to White Americans that Black radicals were hardly more receptive to reform than the string of serial killers, during and around the 1970s, that helped fix public perceptions of lawbreakers as different not only in circumstance but in kind (Simon, 2014: 17-46). In treating such people, there seemed no reason not to venture "beyond the moral outer limits of state-inflicted pain" (Haney, 1998: 32).

Today, the documentation of the effects of limitless pain, and resistance to it, are among the most salient concerns of writing from U.S. prisons. Prison witness documents the precarity of life inside U.S. lockups, the life of those who, while silent, dwell in the American imagination much like enemies in a war, "as a direct threat to life", and so "do not appear as 'lives"” (Brown, 2009; Butler, 2009: 42; Simon, 2014). In writing, in their very documentation of the dissolution of identity, these witnesses (re)present themselves as living beings. Otherwise ungrievable, in their witness they restore their living humanity even in grieving its loss. Malcolm X and Eldridge Cleaver were writers reflecting after the fact, from positions of full survival and political evolution. George Jackson sent out dispatches from amid that transformation. Prison witness today often constitutes "acts that somehow, incredibly, live through the violence they oppose, even if we do not yet know in what ways", or if, "such lives will survive" (Butler, 2009: 62).

\section{Prison Witness Today}

In the fall of 2009, a call went out for first-person essays by incarcerated people documenting their experience inside U.S. prisons. Fourth City: Essays from the Prison in America was published in 2014 (Larson, 2014a). The deadline for that volume passed in fall of 2012, but essays never stopped 
coming, leading to the creation of a digital platform (APWA, 2019). At the time of writing, the APWA hosts 2,168 essays and is the first fully-searchable open-source digital repository of first-person prison witness. It hosts over 2.8 million words of such witness, and it grows by just under 60,000 words each month. These essays are not edited. With a few caveats, essays are scanned and posted exactly as they arrive. ${ }^{6}$

The modern prison has always been intended to keep the public out and silence the condemned, as well as keeping lawbreakers inside (Rush, 1787; Foucault, 1995; Meranze, 1996: 8). All writing that comes from inside is thus an act of resistance (Harlow, 1987; Franklin, 1998: 1). But while prison witness today echoes that of the past in documenting dangerous physical conditions, torture, medical negligence, and dehumanizing cultures and practices (Franklin, 1989), what the APWA makes possible is large-scale aggregation of such witness. Fourth City gathered 71 essays from 27 states. Its title reflects not only the sheer number of people held in U.S. prisons and jails, but the fact that writers in prison reveal concerns as cohesive as we might expect among writers documenting life in New York, Los Angeles, or Chicago (Larson, 2014b: 4). The writers in the APWA thicken this cohesiveness among an essay count equivalent to over 30 volumes the size of Fourth City. What emerges from such aggregation is a broad mapping, from their receiving end, of carceral-state breakdowns in civil society, of policing, courts, and all dimensions of prison practice. My concern in this attempt to make use of this resource is to examine how it unveils an institution that does not simply contain, incapacitate and punish the victims of the neo-liberal carceral-state, but forces them into psychological and emotional degradation from which they often despair of recovering, yet in turn also precipitates remarkable acts of reconstruction. Such witnesses speak for the literally dead and the walking dead, for the prison's "unmade" persons (cf. Levi, 1989; Dayan, 2011). Posting texts exactly as they are composed, the APWA is able to aggregate the in media res work of writers struggling with their own unmaking. The following excerpts are typical of acts of witness's grieving the process, events, and meaning of their dehumanization. ${ }^{7}$

Humanity can fade into mere memory: "Each minute of every day is a slow asphyxiation. The worst death sentence in this country is being buried alive in prison without hope. [...] I know that in me there must be a human being beneath all this agony. It is a faith belief" (Bossé, 2019).

\footnotetext{
${ }^{6}$ For the protection of its writers, the APWA reserves the right to edit or reject work that advocates violence, includes names in ongoing legal cases, or libels named individuals (APWA, 2019). ${ }^{7}$ I have chosen passages that generally describe the effects of shared prison experience. The effects of solitary confinement are also well documented in the APWA; see also Abbott (1991: 46-51).
} 
Sentiment itself is either severely damaged, or must be dismantled:

[...] I look for - but cannot find, the man I was once. Sometimes I stand staring at my disparaging reflection, like a wondering child, of the man I have become. A man that struggles daily with the fading ability to feel the tenderness of the life I once knew [...] from the loss of being able to respond to sentimental tenderness [...]. (Hairgrove, 2019)

To psychologically contend with being treated like a domestic animal is to learn to cope with constant frustration. One way of accomplishing that is by lowering one's expectations of any type of fortune. The process of self-neutering your enthusiasm requires a process of getting indifferent to life. Becoming insensitive to your state of well being and contentment. [...] Barriers. One is forced to build barriers around their feelings, act as though everything is "fine". Slowly and steadily a prisoner creates a figment of themself, a sort of nobody-anybody status. A trademarkless being. A puppet-zero. (Long, 2019)

Simple defense of dignity can - paradoxically - come at the cost of self-alienation:

[I]nmates decided to sexually assault me by beating me relentlessly until I submitted to the rape. This went on for months and the kid in me died. My soul left my body, my heart turned to stone and the blood in my veins turned to ice. One day one of my tormentors entered my cell to stick his penis in my rectum to humiliate and abuse me and I struck him in the head with my fist until he collapsed and continued to beat him until he was a bloody mass of flesh upon my floor [...] Over the next $2 \frac{1}{2} 2$ years I stabbed, beat, choked everyone who entered my cell or challenged me on the recreation yard. I was recruited into a gang and tasked with hurting enemies and informants [...] I was evolved against my will into what I am today. [...] As for me I stopped living long ago. While my heart still beats my mind is a dark void inside which lies horrible thoughts. [...] I do not know what will become of me but I fear it will be terrible for me and for many others. I am broken beyond repair. (Pinson, 2019)

[At] no point during my incarceration did I begin my prison sentence with the intentions of assaulting other prisoners and/or "Correctional Officers", in fact I wanted desperately to change my life and to become rehabilitated, however after observing young men being raped, assaulted, humiliated and broken by both prisoners and prison staff, I came to the conclusion that I would rather kill and/or be killed then end up becoming a victim of your tactics and peers. [...] I realized that if I wanted to survive in this world which you skillfully created, that I would literally have to go numb and become an animal myself. (Gomez, 2019) 
[L]ike falling down a bottomless pit. There's nothing you can do. It's a freefall and gravity forever has you. I stood at the edge of abyss and stared into it. [...] I was a prisoner in body and mind due to the indoctrination and reinforcement by prisoners and correctional officers alike. I was labeled by my peers. I was labeled by the system. The thing is, I accepted those labels because I allowed others to define me and dictate my actions. (Starks, 2018)

The APWA witness sampled above presents not Butler's uncertain "ways" of survival but total uncertainty about survival itself (physical or of identity). At the same time, these are acts of resistance: resistance as memorial, as eulogy to past or passing and otherwise ungrieved lives.

How did we get here? Marie Gottschalk shows how the Warren Court's defense of defendant and prisoner rights in the 1960s created public resentments that led to backlash in today's victims' rights era, in which perpetrators' pain has become the measure of justice. In particular, capital courtrooms became largely expressive, "morality play[s]" weighing the pain that perpetrators deserved by the pain that victims suffered (Gottschalk, 2006: 226). The result is that "The judicial system is judged primarily by its capacity to serve as a vehicle for the expression of private rage, grief, compassion, or mercy, rather than by alternative measures that consider the needs of victims, offenders, and society more broadly" (ibidem: 233; see also Garland, 2002: 102). The excerpts above are just a sampling of testimony to the lived experience of a prison shaped by a judicially imagined (i.e., ideological) and all too concrete translation of victims' grief into perpetrator suffering (Simon, 2009: 77-78), in which "[...] we now celebrate rather than merely tolerate or even lament official cruelty and the infliction of pain" (Haney, 1998: 32). ${ }^{8}$ The APWA is flush with witness to the experience of watching the self degenerate or become unrecognizably transformed. This is writing that in the past would never have reached the public; in it we see a population ready to write about and in this way to resist the full range of damaging effects of the U.S. carceral state from birth to lockup. ${ }^{9}$ Even when these witnesses mark their own passing into "puppet-zeros", they actively defy that passing by demonstrating the wherewithal to write.

Elaine Scarry notes that "to be present when a person moves up out of that pre-language [of pain] and projects the facts of sentience into speech

\footnotetext{
${ }^{8}$ On dissenting judges' condemnation of anti-rationalism in the use of victim impact statements, see Ferguson (2014: 83-84).

9 These effects include birth into domestic violence (e.g. Whitham, 2019), into homes ravaged by drugs (e.g. Di Lenola, 2019) and a normalized prison culture (e.g. Brown, 2019).
} 
is almost to have been permitted to be present at the birth of language itself" (Scarry, 1983: 6; see also Butler, 2009: 61). The range of similes and metaphors in the texts above suggest witnesses struggling to translate pain into language. And such stepping back from the "abyss", facing the carceral regime as a self-aware agent, is the starting point for all other forms of carceral resistance. Malcolm X and Cleaver write of that turn literally after the fact, after resurrection from a previous sense of self. Jackson's letters are journal entries on the path of willfully dying to the body and emotions and rising again. The APWA presents hundreds of instances of people refusing to be consumed by the prison environment. The very act of articulating their experience is the first step by which subjects of trauma resist and begin to recover from their experience (Scarry, 1983: 9; Laub, 1992: 78; Herman, 1997: 181). Such writers at once map the vengeful legal horizon upon which the prison dwells, and trace the personal deaths, inside civil death, marking the gravitational center of the U.S. carceral state. They map the field across which those who actively resist that center must struggle; they reveal too that the latter struggle is rarely endured alone.

Imprisoned people's use of the "we" has been contested whenever it suggests political commitments that the prison refuses to recognize (Naidoo, 1983: 241; Harlow, 1987: 148-153). It is thus worth noting how often the essays excerpted above, marking passage into the "abyss", are seated in an "I". This usage is conspicuously juxtaposed to the "we" (and its equivalents) common in essays describing forward-looking (rather than memorial) resistance. In the archive, the first-person plural most often represents less an explicitly political than a generically collective experience, suggesting awareness of a human yet mass encounter. Writing in resistance entails what "one" faces, what "you" endure, what "we" experience, or it makes explicit reference to others in their social/penal situation. Such essays describe measures taken by the individual actor, yet that are offered to others as exemplary acts. Reconstruction and resistance imply a rising above the singular experience, into behavioral models for the collective.

Travis Cunningham echoes a number of writers who describe taking control of their perspective: ${ }^{10}$

Prison tends to remove those simply human attributes and instead replace them with an abysmal, diabolic, malicious nature, essentially turning a slightly flawed individual into a tyrant. [...] How does one keep their splenetic tendencies in check you ask? Well it's simple, you decide that you want to be above reproach, you make

\footnotetext{
10 Such writers echo the work of Viktor Frankl (1963), cited by several authors in the archive.
} 
a conscious decision to dig deep \& find the mental fortitude that we all have, and utilize it to bring out the virtuous decorum that has remained dormant while you've been held in captivity. The vertigo you feel from living in a place that reduces you to a second class citizen can cause despondency which is why you may feel the need to abdicate any lasting hope of returning to society undamaged. Yet, you must fight back against aberration, and find a way to see the beauty in your existence. There is beauty around us no matter what our physical surrounding may look like. It can be something minuscule like a polite gesture from a fellow prisoner holding the door open for you, or hearing a bird outside your window sing their beautiful song, watching the sun reflect off the cinder block wall \& enjoy being a kid again making hand puppets using the wall as your personal screen. This may all sound like trivial things that many may laugh at which is fine. Maybe, I'd laugh too, had I not gone through days that my depression was so pertinacious it almost caused my early demise. Incarceration can seem opaque for those who haven't lived through it, I'd like to think writing and sharing my thoughts can begin to help others outside of prison hear our voices and empathize with our struggle. (Cunningham, 2019)

Cunningham self-consciously bears witness - as witness for others to his resistance of the path toward "demise", thus reclaiming "the sociality of the self" revealed in mourning and that is inseparable from fully human life (Butler, 2004: 19). In "Finding Freedom Inside of Prison", Stacy Shaw links his social (re)awakening to awareness of collective Black struggle:

In retrospect I was just as much a slave to the system as my beautiful ancestors were slaves to "White America" hundreds of years ago. [...] Perusing through the cathartic story of Malcolm X strongly motivated me to begin the journey of self-education; hearing about the stalwart expeditions of Marcus Garvey imparted in me the necessary wherewithal to lead towards ethical prosperity instead of continuing to lead in the direction of racial destruction. [...] I have acquired from the lessons taught by these extraordinary models of growth and development a curative awakening that has lain dormant in my idle psyche for as long as I can remember. All that I have spoken on thus far can be summed up with one thought: I have truly found the meaning of "FREEDOM". [...] Until we as people take the time to get to know who we truly are, where we came from, and where we are trying to go, we will remain in a bottomless pit of nothingness. (Shaw, 2019)

This "bottomless pit", the "abyss", and the state of the "puppet-zero" are resisted in resituating the self among others. Arizona writer Levert Brookshire III describes "Developing my leadership skills and the ways in which I use them, to influence others" as intrinsic to his ability to "resist 
that 'psychological' hold over me and keep taking my mind in the direction I want to go" (Brookshire, 2019).

Inside a system rife with preventable death and that transfers people seemingly at random, connection is often temporary. Michael Arreygue writes of the value of the mere memory of human bonding.

We both did not engage in drugs, drug use or stupidity that is so rampant in prison [...]. We had our bad times, good times, but as with human beings placed in similarly situated positions they will band together. We did this and helped one another. In more ways than one. Managed our food, income, found ways to gain necessities and unbeknownst to us gave one another emotional support. It is weird how life works at times. I met a friend in an unlikely place. (Arreygue, 2019)

\section{Arline Lawless documents return to self in collective sociality:}

Some women here are still in segregation because they can't handle all the stress here. I was one of those women, only I was not put into segregation. I just stayed in my room and never came out except for meds and sometimes meals. I am here for a good chunk of time and I decided that when I first got here that I was going to sleep my bid away. This worked for almost 2 years. However, there were some women here that I am so glad to have met, just wish that it were under different circumstances they would come to my door and bang on it and yell, "You get out of that bed right now and you come out here and play spades with us". I can tell you that that really boosted my confidence that there were women here that actually gave a shit about me. See we are like a family here. (Lawless, 2019) $)^{11}$

Finally, Daniel Hairgrove touches on the premise underlying all of the writing of all prison witnesses: writing itself is a (re)humanizing act.

Only in written words have I found my way of doing time. Writing for myself as well as for others, depending on meager support from loved ones, have I survived, but my only escape, my only privacy has come from my written words. With a pen I am allowed the liberty to say, to express - "TO FEEL", and when the words are thrown away or destroyed, forever banished by fire, then there can never be reprisal

\footnotetext{
${ }^{11}$ See similar instances of collective sociality in the stories of incarcerated women in Levi and Waldman (2017). The question of the gendered traits of prison witness by women (or men) is simply too large to take on here. Access is also an issue in the context of the APWA, where women are underrepresented (by more than half of the 1:10 ratio of women and men in U.S. incarceration; see APWA, 2019). Other critics have addressed issues specific to woman's prison experience and writing (e.g., McQuaide and Ehrenreich, 1998; Davis and Shaylor, 2001; Law, 2009; Willingham, 2011). Women can also engage in violent physical resistance (e.g. Vanderford, 2019).
} 
for my rebelliousness. Thereby I will have been in touch, through my pen and paper, with contumacy or tenderness and whatever strength that is within me [...] and I have survived [...]. (Hairgrove, 2019)

These witnesses reclaim their identities and dignity as the most fundamental acts of resistance to the carceral state, which - as these and other witnesses testify - assaults their ability to recognize themselves, and others, as human. The gap between state ideology and state practice is measured here by the incremental labor of resisting those practices' most private effects; yet these writers are also aware that they serve as witnesses, as first-person speakers for a wider, collective population and experience. They widen the circle of a "we" pushing back against state violence by blunting its fragmenting effects. Resistance requires a sense of a self that is not only consciously extracted from the carceral state's alienating practices but that reclaims social integration, if only with other incarcerated people. ${ }^{12}$ Witnesses who document the absorption of the self - effected, feared, or merely lamented into the prison environment peek back from inside the lip of the abyss; those who write from atop that lip throw ropes to pull others out.

No matter how closely or broadly we look at texts composed inside the earth's carceral hegemon, we are always looking at moments within a class-action, habeas corpus suit against U.S. prison practice, a class-action chorus that places the prison "on trial". American prisons, as Malcolm X, Cleaver, Jackson, Assata Shakur, Jack Henry Abbott and others have claimed, regularly evoke critical political awareness in their wards. Created from the insistent will of the condemned and allowed to bypass the gatekeepers of print publication, contemporary U.S. prison witness makes clear that political intent is not necessary to political effects; prison witnesses bear "cellular" relations in both the biological and architectural sense: each carries the DNA of the whole; each shares walls with every other (Larson, 2017).

\section{Implications for Scholarly Practice}

Robert Cover also noted that "Legal interpretation takes place in a field of pain and death" (1992: 203). The law is not abstract; it both suppresses and spreads violence by casting legal sanction over the acts of violence carried out by the police, courts, and prisons (cf. Benjamin, 1996: 231-234, 236-252). Cover did not live to see his claims brought home by cell phone videos of police killing unarmed people, and he only tentatively

12 There are, of course, incarcerated people who write in explicit solidarity with larger collectives (James, 2003, 2005). 
pointed toward the corollary to his own claim: without some measure of the human suffering experienced on the receiving end of legal violence, we can never grasp the full human cost of the current legal order. Incarcerated people in the U.S. are taking it upon themselves to document that total from inside the hearts, minds, and bodies forced to pay those costs. In turn, the very existence of an archive that incarcerated people have created could shift the critical grounds for scholars outside: rather than taking the lead in "interpreting" these texts to fit pre-set ends (in orthodox narratives of the politics of mass incarceration), scholars can serve instead as indexers of prison witnesses whose work speaks powerfully for itself; we can serve as secondary witnesses to the labor of the organic intellects now burgeoning among the victims of legalized punishment.

A vital step in combatting mass incarceration is to de-massify its subjects. We can do this by simultaneously recognizing their written efforts to extract themselves, in writing, from the data piles accumulated by state agencies (and from those accumulated by even the most critical efforts of the social sciences), and by acknowledging the status of their writing as representative of the experience of others inside a mass-scale institution, as witness. Seated in narratives of the human costs of incarceration, the APWA invites humanists in particular to rejoin this conversation by bringing their signature, nuanced manners of reading to revealing where individual and collective meet, cross, and graph into one another (Simon, 2010). The U.S. has created a major metropolis in cages. While both countering and supplementing the "big data" approach to carceral statehood with an unfolding of broad narrative witness, scholars can acknowledge the singular identities of individual writers and locate these distinct, cellular identities upon the broad background of mass-scale U.S. incarceration. This is simultaneously self-realizing and collectivizing work that witnesses to incarceration present simply as functions of where they live, why they live there, and what their experience of U.S. criminal justice reveals to them. The task for scholars going forward may be simply to aid this resistance (to the prison's atomizing, identity-degrading work) by reading widely enough to conduct thick indexing of prison witness.

Edited by João Paulo Moreira 


\section{References}

Abbott, Jack Henry (1991), In the Belly of the Beast: Letters from Prison. New York: Knopf.

ACLU - American Civil Liberties Union (2002), "Know Your Rights: The Prison Litigation Reform Act (PLRA)". Accessed on 31.07.2019, at https://www.aclu.org/ sites/default/files/images/asset_upload_file79_25805.pdf.

Agamben, Giorgio (2003), "What Is a Camp?", in Neil Levi; Michael Rothberg (eds.), The Holocaust: Theoretical Readings. New Brunswick: Rutgers University Press, 241-245.

Alexander, Michelle (2010), The New Jim Crow: Mass Incarceration in the Age of Colorblindness. New York: The New Press.

APWA - American Prison Writing Archive (2019), "History, Process, Mission". Accessed on 13.04.2019, at https://apw.dhinitiative.org/collection-description. Améry, Jean (1980), At the Mind's Limits: Contemplations by a Survivor on Auschwitz and Its Realities. Bloomington, IN: Indiana University Press. Translated by Sidney Rosenfeld and Stella P. Rosenfeld.

Arreygue, Michael (2019), "Fate?", The American Prison Writing Archive. Accessed on 11.04.2019, at https://apw.dhinitiative.org/islandora/object/apw\%3A12342742?solr_ nav \%5Bid\%5D=c5402da9d8d33097148d\&solr_nav\%5Bpage\%5D=0\&solr_nav\% 5 Boffset $\% 5 \mathrm{D}=1$.

Benjamin, Walter (1996), Selected Writings, Vol. 1, 1913-1926. Edited by Marcus Bullock and Michael W. Jennings. Cambridge, MA: Belknap Press of Harvard University Press.

Bossé, John Russel (2019), "I Have to Write of My Condition When I Am Safely Distanced from It", The American Prison Writing Archive. Accessed on 11.04.2019, at http:// apw.dhinitiative.org/islandora/object/apw\%3A12342092?solr_nav\%5Bid\%5D= 49f931c02323d6c133a9\&solr_nav\%5Bpage\%5D=9\&solr_nav\%5Boffset $\% 5 \mathrm{D}=6$.

Brookshire, Levert (2019), "Cell Block Society Post-Release Master Plan: Protecting Life First 18 Months Re-Evaluation”, The American Prison Writing Archive. Accessed on 10.04.2019, at https://apw.dhinitiative.org/islandora/object/apw\%3A12342628? solr_nav\%5Bid\%5D=a4ff81399982b3ab21dd\&solr_nav\%5Bpage\%5D=0\&solr_nav $\% 5$ Boffset $\% 5 \mathrm{D}=4$.

Brown, Michelle (2009), The Culture of Punishment: Prison, Society, and Spectacle. New York: New York Umiversity Press.

Brown, Rahasheem (2019), "The Mentality of an Incarcerated Criminal! Part One", The American Prison Writing Archive. Accessed on 10.04.2019, at https://apw. dhinitiative.org/islandora/object/apw\%3A12343765?solr_nav\%5Bid\%5D =65d56 98968d5bc2c449b\&solr_nav\%5Bpage\%5D=0\&solr_nav\%5Boffset\%5D=1.

Butler, Judith (2004), Undoing Gender. New York: Routledge.

Butler, Judith (2009), Frames of War: When Is Life Grievable? New York: Verso. 
Butler, Paul (2017), Chokebold: Policing Black Men. New York: The New Press.

Cleaver, Eldridge (1999), Soul on Ice. New York: Delta [orig. 1968].

Cover, Robert (1992), "Violence and the Word", in Martha Minow; Michael Ryan; Austin Sarat (eds.), Narrative, Violence, and the Law: The Essays of Robert Cover. Ann Arbor: University of Michigan Press, 203-238.

Cunningham, Travis (2019), "Benevolence”, The American Prison Writing Archive. Accessed on 10.04.2019, at https://apw.dhinitiative.org/islandora/object/ apw \%3A12353053.

Davis, Angela (1971), If They Come in the Morning: Voices of Resistance. New York: The Third Press.

Davis, Angela; Shaylor, Cassandra (2001), "Race, Gender, and the Prison Industrial Complex: California and Beyond”, Meridians, 2(1), 1-25. Accessed on 01.08.2019, at http://www.jstor.org/stable/40338793.

Dayan, Colin (2011), The Law is a White Dog: How Legal Rituals Make and Unmake Persons. Princeton, NY: Princeton University Press.

Di Lenola, Jose (2019), “The Years in Between", The American Prison Writing Archive. Accessed on 12.03.2019, at https://apw.dhinitiative.org/islandora/ object/apw\%3A12351312?solr_nav\%5Bid\%5D=450d3d4239d16e9f6376\&s olr_nav $\% 5$ Bpage $\% 5 \mathrm{D}=0 \&$ solr_nav $\% 5$ Boffset $\% 5 \mathrm{D}=1$.

Ferguson, Robert (2014), Inferno: An Anatomy of American Punishment. Cambridge, MA: Harvard University Press.

Foucault, Michel (1995), Discipline and Punish: The Birth of the Prison. New York: Vintage. Translated by Alan Sheridan.

Frankl, Viktor (1963), Man's Search for Meaning: An Introduction to Logotherapy. Boston: Beacon Press.

Franklin, H. Bruce (1989), Prison Literature in America: The Victim as Criminal and Artist. New York: Oxford University Press.

Franklin, H. Bruce (1998), "Introduction”, in H. Bruce Franklin (ed.), Prison Writing in Twentieth-Century America. New York: Penguin Books, 1-18.

Garland, David (2002), The Culture of Control: Crime and Social Order in Contemporary Society. Chicago: Chicago University Press.

Gomez, Billie (2019), "Dear American Justice”, The American Prison Writing Archive. Accessed on 12.04.2019, at http://apw.dhinitiative.org/islandora/object/ apw\%3A12342299?solr_nav\%5Bid\%5D=268fd5efef79d9410d9d\&solr_ nav $\% 5$ Bpage $\% 5 \mathrm{D}=5 \&$ solr_nav $\% 5$ Boffset $\% 5 \mathrm{D}=15$ \#page $/ 1 / \mathrm{mode} / 1 \mathrm{up} / \mathrm{search} /$ timestamp $\% 3 \mathrm{~A} \% 5 \mathrm{~B} \% 2 \mathrm{~A} \% 20 \mathrm{TO} \% 20 \mathrm{NOW} \% 5 \mathrm{D}$.

Gottschalk, Marie (2006), The Prison and the Gallows: The Politics of Mass Incarceration in America. New York: Cambridge University Press.

Haney, Craig (1998), "Riding the Punishment Wave: On the Origins of Our Devolving Standards of Decency”, Hastings Women's Law Journal, 9(1), 27-78. 
Hairgrove, Donald (2019), “A Day in Life”, The American Prison Writing Archive. Accessed on 12.04.2019, at http://apw.dhinitiative.org/islandora/object/ apw\%3 A12342163 ?solr_nav\%5Bid\%5D=e769ab8225b0a316fca0\&solr_ nav $\% 5 B$ page $\% 5 \mathrm{D}=9 \&$ solr_nav $\% 5$ Boffset $\% 5 \mathrm{D}=10$ \#page $/ 1 /$ mode/1up/search/ timestamp \%3A\%5B\%2A\%20TO\%20NOW\%5D.

Harlow, Barbara (1987), Resistance Literature. New York: Methuen.

Herman, Judith (1997), Trauma and Recovery: The Aftermath of Violence - From Domestic Abuse to Political Terror. New York: Basic Books.

Holbrook, Robert Saleem (2019), "From Public Enemy to Enemy of the State", The American Prison Writing Archive. Accessed on 12.04.2019, at https://apw. dhinitiative.org/islandora/object/apw\%3A12351243?solr_nav\%5Bid\%5D=89189 a3a91ef1e46d9c0\&solr_nav\%5Bpage \%5D=0\&solr_nav $\% 5$ Boffset $\% 5 \mathrm{D}=0$.

Irwin, John (1980), Prisons in Turmoil. Boston, MA: Little Brown.

Jackson, George (1994), Soledad Brother: The Prison Letters of George Jackson. Chicago: Lawrence Hill [orig. 1970].

James, Joy (ed.) (2003), Imprisoned Intellectuals: America's Political Prisoners Write on Life, Liberation, and Rebellion. New York: Rowman \& Littlefield.

James, Joy (2005), The New Abolitionists: (Neo)Slave Narratives and Contemporary Prison Writings. Albany, NY: State University of New York Press.

Knight, Ethridge (1986), The Essential Ethridge Knight. Pittsburgh, PA: Pittsburgh University Press.

Larson, Doran (ed.) (2014a), Fourth City: Essays from the Prison in America. East Lansing, MI: Michigan State University Press.

Larson, Doran (2014b), "Introduction”, in Doran Larson (ed.), Fourth City: Essays from the Prison in America. East Lansing, MI: Michigan State University Press, 1-10.

Larson, Doran (2017), Witness in the Era of Mass Incarceration: Discovering the Ethical Prison. Madison, NJ: Fairleigh-Dickson University Press.

Laub, Dori (1992), “An Event Without a Witness: Truth, Testimony, and Survival”, in Shoshana Felman; Dori Laub (eds.), Testimony: Crises of Witnessing in Literature, Psychosis, and History. New York: Routledge, 75-92.

Law, Victoria (2009), Resistance Behind Bars: The Struggles of Incarcerated Women. Oakland, CA: PM Press.

Lawless, Arline (2019), "Descriptions of Sources of Stress, and Ways of Coping”, The American Prison Writing Archive. Accessed on 11.04.2019, at https://apw. dhinitiative.org/islandora/object/apw\%3A12351574? ?solr_nav\%5Bid \%5D=cea32 c79bd9ccf4c81b5\&solr_nav\%5Bpage\%5D=0\&solr_nav\%5Boffset \%5D=13.

Levi, Primo (1989), The Drowned and the Saved. New York: Vintage International. Translated by Raymond Rosenthal.

Levi, Robin; Waldman, Ayelet (eds.) (2017), Inside this Place, not of It: Narratives from Women's Prisons. New York: Verso. 
Long, Stephen (2019), “A Prisoner's Essays”, The American Prison Writing Archive. Accessed on 10.04.2019, at https://apw.dhinitiative.org/islandora/object/apw\%3 A12342869?solr_nav\%5Bid\%5D=4cd501ebaf8e4977ec48\&solr_nav\%5Bpage \% $5 \mathrm{D}=0 \&$ solr_nav $\% 5$ Boffset $\% 5 \mathrm{D}=4$.

Lyon, Patrick (1799), The Narrative of Patrick Lyon, Who Suffered Three Months Severe Imprisonment in Philadelphia Gaol; on Merely a Vague Suspicion, of Being Concerned in the Robbery of the Bank of Pennsylvania: With His Remarks Thereon. Accessed on 05.04.2019, at https://quod.lib.umich.edu/cgi/t/text/text-idx?c=evans;cc=evans;vie $\mathrm{w}=$ text;idno=N26860.0001.001;rgn=div1;node=N26860.0001.001:3.

Malcolm X (1965), The Autobiography of Malcolm X. New York: Grove.

Mauer, Marc (2006), Race to Incarcerate. New York: Free Press.

McQuaide, Sharon; Ehrenreich, John H. (1998), "Women in Prison: Approaches to Understanding the Lives of a Forgotten Population”, Affilia, 13(2), 233-246. Accessed on 01.08.2019, at https://doi.org/10.1177/088610999801300207.

Meranze, Michael (1996), Laboratories of Virtue: Punishment, Revolution, and Authority in Philadelpbia, 1760-1835. Chapel Hill: University of North Carolina Press.

Naidoo, Indres (1983), Robben Island: Ten Years as a Political Prisoner in South Africa's Most Notorious Penitentiary. London: Penguin Books.

Obama, Barack (2013), "Remarks by the President on Trayvon Martin”, July 19. Accessed on 25.03.2019, at https://obamawhitehouse.archives.gov/the-press-office/2013/07/19/ remarks-president-trayvon-martin.

O’Hare, Kate Richards (1920), In Prison. St. Louis, MO: F. P. O’Hare.

Pinson, Jeremy (2019), "Life in Solitary Confinement", The American Prison Writing Archive. Accessed on 29.03.2019, at http://apw.dhinitiative.org/islandora/ object/apw\%3A12342232?solr_nav\%5Bid\%5D=26daf9a14bd7ab0145a1\&s olr_nav $\% 5$ Bpage $\% 5 \mathrm{D}=5 \&$ solr_nav $\% 5$ Boffset $\% 5 \mathrm{D}=4$ \#page $/ 1 / \mathrm{mode} / 1 \mathrm{up} / \mathrm{search} /$ timestamp \%3A\%5B\%2A\%20TO\%20NOW\%5D.

Reiter, Keramet (2016), 23/7: Pelican Bay Prison and the Rise of Long-Term Solitary Confinement. New Haven: Yale University Press.

Robbins, Tom (2015), "Brutal Beating Wakes Attica’s Ghosts”, The New York Times, February 28. Accessed on 31.07.2019, at https://www.nytimes.com/2015/03/01/ nyregion/attica-prison-infamous-for-bloodshed-faces-a-reckoning-as-guards-goon-trial.html.

Rodriguez, Dylan (2006), Forced Passages: Imprisoned Radical Intellectuals and the U.S. Prison Regime. Minneapolis: University of Minnesota Press.

Rush, Benjamin (1787), "An Enquiry into the Effects of Public Punishments upon Criminals, and upon Society”, Evans Early American Imprint Collection. Accessed on 25.03.2019, at https://quod.lib.umich.edu/e/evans/N16141.0001.001/1:2?cite1 $=$ Rush $\% 2 \mathrm{C}+$ Benjamin; cite1 restrict=author;hi=0;rgn=div1;view=fulltext;q1=punis hments;op2=and; $2=$ public. 
Scarry, Elaine (1983), The Body in Pain: The Making and Unmaking of the World. New York: Oxford University Press.

Shakur, Assata (1987), Assata: An Autobiograpby. Westport, CT: Lawrence Hill.

Shaw, Stacy (2019), "Finding Freedom Inside of Prison”, The American Prison Writing Archive. Accessed on 01.04.2019, at https://apw.dhinitiative.org/islandora/object/apw\%3A12352623?solr_nav\%5Bid\%5D=c00645645747240911b6\&s olr_nav $\% 5$ Bpage $\% 5 \mathrm{D}=0 \&$ solr_nav $\% 5$ Boffset $\% 5 \mathrm{D}=2$.

Simon, Jonathan (2000), “The 'Society of Captives' in the Era of Hyper Incarceration”, Theoretical Criminology, 4(3), 285-308.

Simon, Jonathan (2009), Governing Through Crime: How the War on Crime Transformed American Democracy and Created a Culture of Fear. New York: Oxford University Press.

Simon, Jonathan (2010), "Beyond the Panopticon: Mass Imprisonment and the Humanities”, Law, Culture and the Humanities, 6(3), 327-340.

Simon, Jonathan (2014), Mass Incarceration on Trial: A Remarkable Court Case and the Future of Prisons in America. New York: Free Press.

Smith, Caleb (2009), The Prison \& the American Imagination. New Haven, CT: Yale University Press.

Snelling, William Joseph (1837), The Rat-Trap, or, Cogitations of a Convict in the House of Correction. Boston, MA: G.N. Thomson, Weeks, Jordan \& Co.

Starks, Derrick (2018), "Neuroplasticity Inside the Ghetto", The American Prison Writing Archive. Accessed on 28.03.2019, at https://apw.dhinitiative.org/islandora/ object/apw\%3A12353526.

Stuntz, William J. (2001), The Collapse of American Criminal Justice. Cambridge, MA: Belknap Press of Harvard University Press.

Thompson, Heather Ann (2016), Blood in the Water: The Attica Prison Uprising of 1971 and Its Legacy. New York: Pantheon Books.

Travis, Jeremy; Western, Bruce (2017), “Do Black Lives Matter to the Courts?”, in Angela J. Davis (ed.), Policing the Black Man: Arrest, Prosecution, and Imprisonment. New York: Pantheon, 294-321.

Uggen, Christopher; Manza, Jeff (2004), "Lost Voices: The Civil and Political Views of Disenfranchised Felons", in Mary Patillo; David Weiman; Bruce Western (eds.), Imprisoning America: The Social Effects of Mass Incarceration. New York: Russell Sage, 165-204.

Vanderford, Anna (2019), “Gargle, Rinse, Repeat”, The American Prison Writing Archive. Accessed on 27.03.2019, at https://apw.dhinitiative.org/islandora/ object/apw\%3A12353071?solr_nav\%5Bid\%5D=cea32c79bd9ccf4c81b5\&s olr_nav\%5Bpage $\% 5 \mathrm{D}=0 \&$ solr_nav $\% 5$ Boffset $\% 5 \mathrm{D}=17$.

Wacquant, Loïc (2009), Punishing the Poor: The Neoliberal Government of Social Insecurity. Durham, NC: Duke University Press. 
Western, Bruce (2006), Punishment and Inequality in America. New York: Russell Sage. Whitham, George (2019), "Friendship", The American Prison Writing Archive. Accessed on 28.03.2019, at https://apw.dhinitiative.org/islandora/object/ apw\%3A12345514?solr_nav\%5Bid\%5D=1a292eaa9de57f87ed25\&solr_nav\%5 Bpage $\% 5 \mathrm{D}=0 \&$ solr_nav $\% 5$ Boffset $\% 5 \mathrm{D}=0$.

Willingham, Brea (2011), "Black Women's Prison Narratives and the Intersection of Race, Gender, and Sexuality in US Prisons", Critical Survey, 23(3), 55-66. Accessed on 01.08.2019, at https://www.law.columbia.edu/sites/default/files/microsites/ gender-sexuality/Gender_Justice_Fall_2018/willingham_breea_-_black_womens_ prison_narratives.pdf.

Received on 13.04.2019

Accepted for publication on 19.07.2019

\author{
Doran Larson \\ Walcott-Bartlett Professor of Literature \& Creative Writing, Hamilton College \\ 198 College Hill Road, Clinton, NY 13323-1218, United States of America \\ Contact: dlarson@hamilton.edu \\ ORCID: https://orcid.org/0000-0002-3291-1509
}

\section{Escrever a resistência, escrever o eu: reconstrução literária em testemunhos de prisão nos Estados Unidos}

Baseado num arquivo digital de testemunhos na primeira pessoa de reclusos atualmente encarcerados nos Estados Unidos (EUA), este artigo discute textos que documentam e refletem o sofrimento daqueles que passam pela experiência de alienação da autoidentidade, que combatem essa alienação e que, juntos, mapeiam a degradação da dignidade humana no seio do atual sistema penal dos EUA e como esta pode ser combatida para recuperar a sociabilidade com outros reclusos. Escrever do seu interior representa muitas vezes um

\section{Écrire la résistance, écrire le moi: reconstruction littéraire en témoignages de prison aux États-Unis}

Fondé sur une archive numérisée de témoignages à la première personne par d' actuels déténus aux États-Unis (EUA), cet article se penche sur des textes qui documentent et reflètent la souffrance de ceux qui traversent l'expérience d'aliénation de l'identité de soi, qui luttent contre cette aliénation et qui, ensemble, géographisent et tracent les contours de la dégradation de la dignité humaine au sein de l'actuel système pénal des EUA et la façon dont elle peut être combattue pour récupérer la sociabilité avec d'autres 
momento não apenas de resistência ao regime prisional, mas também de reconstrução do eu, que é a premissa de toda a resistência subsequente. Confrontando o testemunho atual ao contexto de um testemunho de uma era penal anterior, o artigo analisa os padrões dos textos publicados nos dias de hoje no American Prison Writing Archive (APWA). A análise sugere que a própria disponibilização do APWA poderá re-definir os futuros estudos académicos sobre as prisões dos EUA. Palavras-chave: arquivo; dignidade humana; Estados Unidos da América; prisão; socialização; testemunho. détenus. Écrire de l'intérieur représente souvent un moment, non seulement de résistance au régime carcéral, mais aussi de reconstruction du moi, prémisse de toute résistance sous-jacente. Après avoir placé le témoignage actuel de la prison d'aujourd'hui dans le contexte d'un témoignage d'une époque pénale antérieure, cet article examine les tendances observées dans les essais publiés aujourd'hui dans l'American Prison Writing Archive (APWA). L'analyse suggère que la mise à disposition de l'APWA pourra re-définir les futures recherches académiques sur les prisons des EUA.

Mots-clés: archive; dignité humaine; États-Unis d'Amérique; prison; socialisation; témoignage. 
